\title{
CRYPTANDRA EXILIS SP. NOV. (RHAMNACEAE), A NEW SPECIES FROM EASTERN TASMANIA
}

\author{
by D.I. Morris
}

(with one table and one text-figure)

Cryptandra exilis sp. nov. (Rhamnaceae), a new species from eastern Tasmania, is described and figured. The new species has affinities with $C$. alpina Hook. f. to which it is compared.

Key Words: Tasmania, Cryptandra, Rhamnaceae.

In BANKS, M.R. et al. (Eds), 1991 (31:iii): ASPECTS OF TASMANIAN BOTANY - A TRIBUTE TO WINIFRED CURTIS.

Roy. Soc. Tasm. Hobart: 57-58. https://doi.org/10.26749/rstpp.124.2.57

\section{Cryptandra exilis D.I. Morris, sp. nov.}

Fruticulus usque ad $40 \mathrm{~cm}$ altus. Rami graciles, procumbentes veleffusi, ramulipilis adpressis, simplicis, antrorsis. Folia 2-7 mm longa, in fasciculos in ramis brevibus lateralibus aggregata, arcte conduplicatoteretia, apice breviter mucronato. Florae ad apicem ramulorum principalium una 2-6 fasciculatae vel interdum solitariae. Bracteae fuscae, scariosae, ad margines ciliatae, ad medium tubi floralis attingentes. Tubus floralis c. $2 \mathrm{~mm}$ longus, dense stallato-pillosus; lobi calysis c. $1.5 \mathrm{~mm}$ longi, basi stellato-piiosi, ad apicem pilis simplicibus erectis. Stylus c. $2.5 \mathrm{~mm}$, longus. Capsula ad maturitatem c. $2.5 \mathrm{~mm}$ longa, basis gibbosa ovarii glabra vel sub-glabra. Semen c. $1.5 \mathrm{~mm}$ longum, atro-maculatum.

\section{Typus}

Tasmania: East Coast (regions as Orchard 1988)Apsley River, A. Moscal 439, 10.v.1980. Holotypus: HO 119721. Isotypus: AD.

\section{Description}

Subshrub up to $400 \mathrm{~mm}$ high. Stems slender, procumbent or straggling, young branches with antrorse appressed simple hairs. Leaves $2-7 \mathrm{~mm}$ long in fascicles on short lateral branches, tightly infolded-terete, apex shortly mucronate. Flowers in clusters of $2-6$ or occasionally solitary, at the tips of the main branches. Bracts dark brown, scarious, margins ciliate, extending to about the middle of the floral tube. Floral tube c. $2 \mathrm{~mm}$ long, densely stellate-hairy, calyx lobes c. $1.5 \mathrm{~mm}$ long, stellate hairy at the base, with simple erect hairs at the apex. Style c. $2 \mathrm{~mm}$ long. Mature capsule c. $2.5 \mathrm{~mm}$ long, the expanded base of the ovary glabrous or sub-glabrous. Seed c. $1.5 \mathrm{~mm}$ long, buff, with darker mottling.

The name of the new species means slender and refers to the habit of the plant. The plant is illustrated in figure 1 (p. 58).

\section{Distribution}

Tasmania: coastal and near-coastal heaths between The Gardens, north of St Helens, and Tasman Peninsula.

\section{Specimens Examined}

Tasmania:East Coast - J.G. Simmons s.n. (HO); M. \& J. Simmons s.n. (HO); W.D. Jackson s.n. (HO). [Further details of specimens listed in this paper, e.g. collecting site and date, are available from the Herbaria noted or from the Royal Society of Tasmania Library (Archives), GPO Box 1166M, Hobart, Tasmania, Australia 7001. $E d$.]

\section{Discussion}

The closest affinities of Cryptandra exilis are with C. alpina Hook. f. It differs from this species in a number of characteristics, as shown in table 1 (p.58).

Cryptandra exilis differs from $C$. ericoides $\mathrm{Sm}$. in having no appressed simple hairs on the floral tube and in having a few simple and stellate hairs only at the base of the style.

Cryptandra exilis is known only from eastern Tasmania where it occurs in coastal and near-coastal heathlands at altitudes below $200 \mathrm{~m}$. It has been recorded at a number of locations between The Gardens, north of St Helens, and Tasman Peninsula.

\section{REFERENCE}

ORCHARD, A.E., 1988: A natural regions map for Tasmania. Pap. Proc. R. Søc. Tasm. 122: 47-51.

(accepted 4 May 1990)

\section{D.I. Morris}

Tasmanian Herbarium, GPO Box 252C, Hobart, Tasmania, Australia 7001 

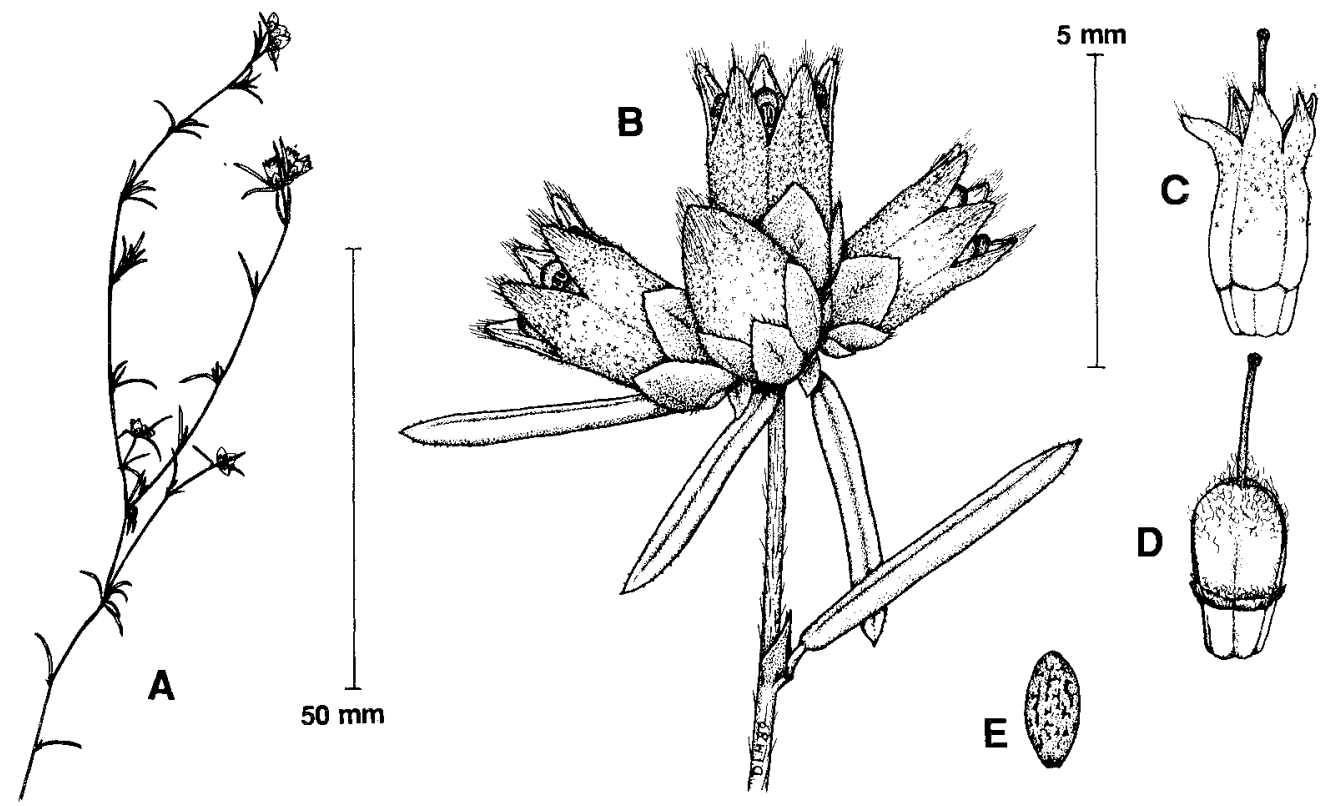

FIG. 1-Cryptandra exilis: (A) flowering branch, $(B)$ cluster of flowers, $(C)$ mature capsule enclosed in persistent floral tube, (D) mature capsule with floral tube removed, (E) seed. Scale lines: (A) $50 \mathrm{~mm}$, (B-E) $5 \mathrm{~mm}$. (Drawn from: A, B-Simmons s.n. (HO 40518); C, D, E-Jackson s.n. (HO 101271).)

TABLE 1

Comparison between Cryptandra exilis sp. nov, and $C$. alpina

\begin{tabular}{lll}
\hline Character & \multicolumn{1}{c}{ C. exilis } & \multicolumn{1}{c}{ C. alpina } \\
\hline Hairs on young branches & Simple, adpressed, antrorse & Stellate and simple mixed \\
Flowers & Usually in clusters of (2-)4-6 & Usually solitary \\
$\begin{array}{l}\text { Ovary base on mature } \\
\text { capsule }\end{array}$ & Glabrous or sub-glabrous & Stellate-hairy \\
$\begin{array}{l}\text { Seed } \\
\begin{array}{l}\text { Distribution } \\
\text { Buff with darker mottling }\end{array}\end{array}$ & $\begin{array}{l}\text { Red-brown } \\
\text { East coast, coastal and } \\
\text { near-coastal below } 200 \mathrm{~m} \text { a.s.l. }\end{array}$ & $\begin{array}{l}\text { Central Highlands and } \\
\text { Ben Lomond floristic regions } \\
\text { between } 975 \text { and } 1040 \mathrm{~m} \text { a.s.1. }\end{array}$
\end{tabular}

